\title{
Issues of the Preservation and Conservation of the Petroglyph in the Khoid Tsenkher Cave
}

\author{
Khishigdalai Ulaankhuu ${ }^{1, *}$, Bat-Erdene Nyandag ${ }^{2}$, and Avirmed Erdene-Dalai ${ }^{3}$ \\ ${ }^{1}$ School of Business, Mongolian University of Humanities, 14200-0031 Ulaanbaatar, Mongolia \\ ${ }^{2}$ School of Engineer and Technology, Mongolian University of Life Sciences, 17024 Ulaanbaatar, Mongolia \\ ${ }^{3}$ Institute of Geographical Sciences, Ulaanbaatar, Mongolia
}

\begin{abstract}
The Khoid Tsenkher Cave is located $28 \mathrm{~km}$ away from the center of Mankhan soum, Khovd province in Mongolia. The cave contains about 40,000-year-old petroglyphs. A variety of animals were depicted on the surface of the rocks, such as ostriches, camels, lions, elephants, and buffaloes in red and light brown paints. These images prove the existence of the animals that became extinct a long time ago. These petroglyphs play an important role in the research of the history and culture of the Paleolithic period of the world due to its visual content and design methods. Unfortunately, 64 images and symbols were faded and became unknown due to the wrong action of the people and new carvings have been created on them. The cave is visited by about 5,000 international and domestic tourists a year, but they cannot actually see the main attraction and do not have the chance to understand its great value. Therefore, there is an opportunity to develop tourism by involving local people in the preservation and conservation process of the cave and its historical and cultural monuments.
\end{abstract}

\section{Introduction}

The Khoid Tsenkher Cave, located in Mankhan soum, Khovd province is one of the nine wonders of Mongolia. The cave contains a historical monument with petroglyphs from 40,000 years ago (Mongolian National Public Website, February 13, 2017).

Citizens' Representatives Khural of Khovd province developed the "Five Stars with Gurvan Tsenher Tuv" program in 2017 and created 5 itineraries of the Khoid Tsenkher Cave in order to develop tourism in Khovd province (Mongol garag, October 4, 2018).

In recent years, the rare and unique historical monuments are in danger of extinction due to the misconduct of domestic travelers. Therefore, there is a need to develop tourism through the preservation and conservation of the caves and introduce the values of its monuments to the public. This study was conducted according to these needs and requirements.

This study aims to identify the ways to develop tourism by improving the preservation and conservation of the petroglyphs in the Khoid Tsenkher Cave.

\section{Methodology of the study}

Many different methods were used, such as field research, source research, analysis, summarization, and comparison. A field research was conducted in the Khoid Tsenkher Cave on September 12th to 15th, 2019. The findings of the research includes the percentages of the petroglyphs that cannot be identified compared to its original images collected by researchers Namnandorj.O, Pavel Pouh, and Okladnikov.A.P. The research on defining the current condition of the tourism was conducted and the ways of developing tourism by preserving the historical and cultural monuments of Khoid Tsenkher Cave has been identified.

\section{Literature review}

The Khoid Tsenkher Cave is located 28 kilometers from the center of Mankhan soum, Khovd province at $47^{\circ}$ $20^{\prime} 49.23$ " north latitude, $91^{\circ} 57^{\prime} .20 .67$ " east longitude and 1649 meters above sea level. It consists of one large and one small cave. The walls and ceiling of the southeast corner of the large cave are full of ancient petroglyphs. (MET, 2019).

Namnandorj.O was the first to study and report the petroglyphs in 1925 and he also sketched some of the images. (Namnandorj.O, 2003).

Pavel Pouch, a Czech expert on medieval Mongolian history, published the images of the petroglyphs in his book called "Thirteen Thousand Kilometers in Mongolia". (Poucha, 1957).

Russian-Mongolian archeological expedition team led by Okladnikov.A.P conducted a full-scale documentation of the cave in 1966.

Okladnikov.A.P studied the petroglyphs of the Khoid Tsenkher Cave, discovered 13 groups of images and symbols, and fpublished them in his book "Central Asian Hearth of Primitive Art" in 1972. (Okladnikov.A.P 1972).

\footnotetext{
${ }^{*}$ Corresponding author: khishigdalai@humanities.mn
} 
Mongolian and Russian archaeologists have also analyzed the petroglyphs and determined that they date back to the Upper Paleolithic (20,000-15,000 years ago) (Mongolian Historical Dictionary).

The cave is visited by about 5,000 international and domestic tourists a year.

International and domestic tourists are divided into 2 general groups.

- Tourist visiting the cave

- Tourists traveling through the area to other destinations.

Passers-by include the Khoid Tsenkher Cave on their Bayan-Ulgii province and Eagle Festival itinerary.

The itinerary of 175 tour operators, members of the Mongolian Tourism Association were analyzed and there are 35 tour programs of 23 tour operators included Khovd province in their itinerary. (MET, 2019).

There are 12 programs of 10 tour operators that included the Khoid Tsenkher Cave in their itinerary. These tour operators are "Khongor expedition", "Sunpath Mongolia tour", "BT\&TC Travel”, "Discover Mongolia", "Jtour", "Steppe nomad", "Steppes journey", "Nomads tours", "Off road" and "Nomex".

There are 6 tour programs of 4 tour operators that organize trips to Khovd province and which means the area became the transit point for Bayan-Ulgii province. These 4 tour operators are "BT\&TC Travel", "Discover Mongolia", "Mongolica", and "Nomads tours", but "BT\&TC Travel" and "Nomads tours" are the only two operators that organize trips to the Khoid Tsenkher Cave. The other two operators provide trip to other attractions in Khovd province. The package tours include the following activities:

- Photo safari (the bird sighting trip to Khar-Us Lake, the snow leopard sighting trip to Jargalant Khairkhan, the saiga sighting trip to Sharga Mankhan Reserve)

- Hiking (the hiking trip to Tsambagarav, the hiking trip Sutai Khairkhan)

- Horse riding trip (Horse riding trip to Tsambagarav, Horse riding trip to Buyant river)

- Eagle Festival (passing through Khovd province on the way to the Eagle Festival)

- Hunting tourism (argali and ibex hunting)

- Jeep tour ( a round trip)

- Ethnographic tour (a round trip)

- Exploration trip (a round trip)

According to these trips, Khovd province became a destination of special interest tourism.

There are 23 hotels, tourist camps and resorts with an average capacity of 780 people in Khovd province, but only one tourist camp is operating near the Khoid Tsenkher Cave (MET, 2019).

There are no accommodation and facilities other than the tourist camp near the cave.

There is a parking lot, a garbage can and a toilet made out of natural stones at the bottom of the cave, but it is too old to be used. The road to the cave is fenced with natural stones.
Road signs (4-5 information boards) are placed at the parting point from Mankhan soum to the cave, and alongside of the $28 \mathrm{~km}$ unpaved road to the cave.

The Khoid Tsenkher Cave-based partnership is currently underdeveloped.

"Silver Plunge" snow and ice festival has been held annually since 2009. "Biy bielgee festival", "International khuumii festival", "Tuuli tsuur festival", and "Altan khelkhee" contortion festival were organized every two years to promote multi-ethnic heritage. It was decided to combine the festivals during the "Tea Road Heritage Festival" and it became the tourism event since 2018 (MET, 2019).

\section{The result}

The comparison of the petroglyphs of the Khoid Tsenkher Cave with the images drawn by Namnandorj.O, Pavel Pouh, and Okladnikov.A.P shows the following results:

- There are 2 lines left from the 14 symbols in group 1.

- There 22 images and symbols have been preserved from 23 images in group 2.

- There are no images of animals and symbols from 3 animal images and symbols in group 3 .

- There are 8 animal images have been preserved from 10 and 2 symbols from 14 in group 4

- All the symbols have been preserved in group 5 .

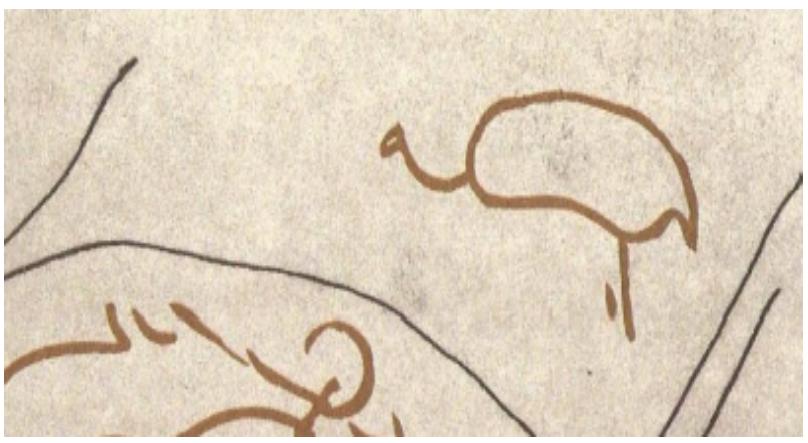

Fig. 1. Part of image in group 5 (Main image).

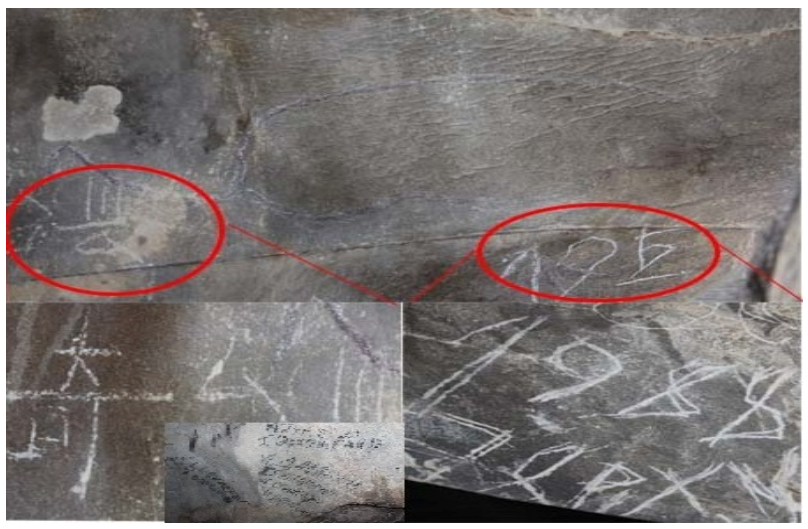

Fig. 2. Part of image in group 5 (Current image) Note: Damage due to human wrong action is highlighted.

- There are an image of argali and 4 spots have been preserved from one image and 3 symbols in group 6 . 


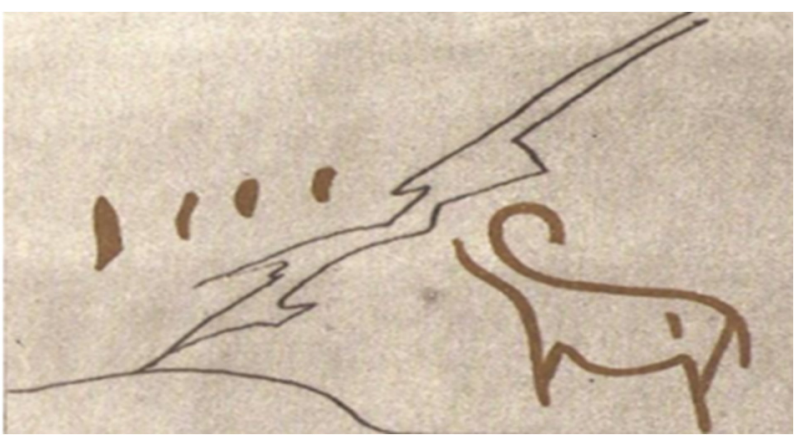

Fig. 3. Part of image in group 6 (Main image).

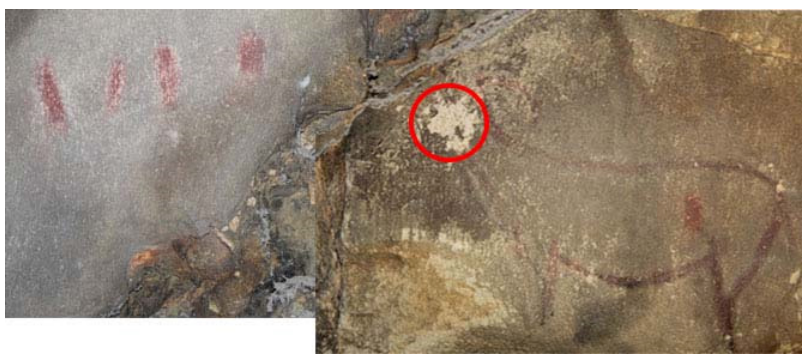

Fig. 4. Part of image in group 6 (Current image) Note: Damage due to human wrong action is highlighted.

- The nine sets of schematic symbols were disappeared in group 7.

- The two oval spots were faded in group 8.

- The image of a camel has been preserved, but other 2 images were disappeared from 4 images in group 9.

- The 2 out of 4 images have been preserved and other 2 images were disappeared in group 10.

- There are 5 images have been preserved from 24 in group 11.

- The 35 images were faded and cannot be seen in group 12.

- All 9 images in group 13 are no longer visible.

Okladnikov.A.P's book, published in 1972, contains a total of 108 images and symbols of the Khoid Tsenkher Cave and as of today, 64 images and symbols have faded and become unrecognizable. Fortunately, 40 images and symbols can be seen, but they have been highlighted and blurred.

In addition, there is a lot of dust in the cave and a lot of new text and images have been drawn and added. Dust level has reached its limit and makes it hard to take pictures and breathe in the cave. In the afternoon, mold and fungus begin to form on the walls.

In terms of tourism, the cave attracts tourists, but it has the following strengths and weaknesses.

Table 1. SWOT analysis of tourism in the Khoid Tsenkher Cave

\begin{tabular}{|c|c|}
\hline Strengths & Weaknesses \\
\hline $\begin{array}{l}>\text { Rare historical and } \\
\text { cultural monument. } \\
>\text { Nomadic culture, } \\
\text { customs, traditions }\end{array}$ & $\begin{array}{l}\text { Due to the lack of } \\
\text { recognition of the } \\
\text { value and importance } \\
\text { of history and culture, } \\
\text { the destruction of rare }\end{array}$ \\
\hline
\end{tabular}

and ethnographic

features.

$>$ It has rich historical and cultural resources.

$>$ It is located along the right axis of the five vertical axes of economy.

$>$ It has many beautiful and unique places that are not discovered by tourists.

$>$ Special interest and adventure tourism, such as hunting, animal sighting and bird sighting are relatively developed in the province.

$>$ Local people started participating in tourism in the form of partnerships.

$>$ Independent tourism program has been developed and implemented. historical and cultural monuments has been destroyed.

$>$ Domestic and international tourists visiting the cave are returning without being able to find the value of the petroglyphs.

$>$ Distant from Ulaanbaatar.

$>$ There is a lack of opportunities to combine historical and cultural monuments with highly developed special interest tours in the province. This is due to the fact that tourists with special interest travel only based on their interests and hobbies.

$>$ Tourist accommodation and facilities are not abundant.

$>$ Poor infrastructure from Mankhan soum to the cave.

$>$ Cognitive development can be combined with other resources, but these resources are not fully recognized in the market.

$>$ Tour operators often choose it as a transit point.

\section{Opportunities}

$>$ Promote the value and importance of historical and cultural monuments to the public

\section{Renovation}

$>$ Provide a local guide to inform tourists about conservation and preservation.

\section{Threats}

$>$ Danger of destruction of historical and cultural monuments caused by the activities of domestic travelers.

$>$ Failure to implement integrated tourism policy and planning 


\begin{tabular}{|l|l|}
\hline \multicolumn{1}{|l|}{$\begin{array}{l}\text { Develop an itinerary } \\
\text { with nearby natural }\end{array}$} & will lead to \\
attractions & unregulated tourism. \\
$>$ & It may bring many \\
Create an independent & dangers. For example: \\
historical and cultural & soil erosion, cave \\
tourism itinerary. & destruction and \\
$>$ Increase the quantity & damage and changes \\
of accommodation & in ecosystem. \\
and facilities. & \\
\hline
\end{tabular}

Therefore, the following activities should be implemented in order to develop the tourism by improving the conservation and preservation of the cave.

1. Preservation and conservation of historical and cultural monuments and management

- Cleaning up the accumulated bird droppings to reduce dust

- Building the road in the cave with sensory lighting for tourists (permanent lighting is not suitable and may increase the mold on the walls)

- Clearing the new texts and images created in the cave

- Changing the steep floor by fixing the natural stones and planning the rest area

- Providing the cave with a permanent guideinterpreter to show and explain the petroglyphs in the cave. In addition, it can prevent from the new text and images on the cave walls and the destruction of valuable ancient monuments

2. Redecoration of the reception area and management

- Building the parking lots, toilets, trash can, benches and information boards that reflect the value of historical and cultural monuments. Place rules and reminders to follow when entering the cave.

- Camping site and parking space

- Maintenance, cleaning, preservation and conservation of reception area.

3. Strengthening the stakeholders' cooperation and their partnerships

- Involving local people in the conservation and preservation process

- Creating a training program and implementing them among the local people

- Creating conditions for local governments, experts, business organizations, nongovernmental organizations and local communities to cooperate effectively.

- Stabilizing joint meetings and discussions of stakeholders and organizing events

\section{Conclusions}

In conclusion, 64 images and symbols, or about 50 percent of petroglyphs of the Khoid Tsenkher Cave have faded and become unrecognizable due to the wrong action of people who visit the cave. It shows that the cave is in need for preservation and conservation.

Also there is a tourism in that area, but tourists cannot see the value of the history and culture because there is no appropriate organization. The newly written and drawn texts and images can prove it.

Therefore, the tourism can be developed by involving local people in the preservation and conservation process of historical and cultural monuments.

\section{References}

1. Poucha, P. P., Trineet tisic kilometer Mongolisken. (1957).

2. Okladnikov.A.P., "Central-Asian hearth of primitive art" (petroglyphs - The Khoid Tsenkher Cave (Sengri cave) Novosibirsk, (1972).

3. MET., The Khoid Tsenkher Cave Tourism Management Plan, (2019).

4. Mongol garag. (2018-10-4). From http://www.mongolgarag.mn/info/115

5. Mongolian Historical Dictionary. (n.d.). From https://mongoltoli.mn/history/h/260

6. Mongolian national public website. (2017-02-13). From http://www.mnb.mn/i/108708

7. Namnandorj.O., Boti, (2003). 